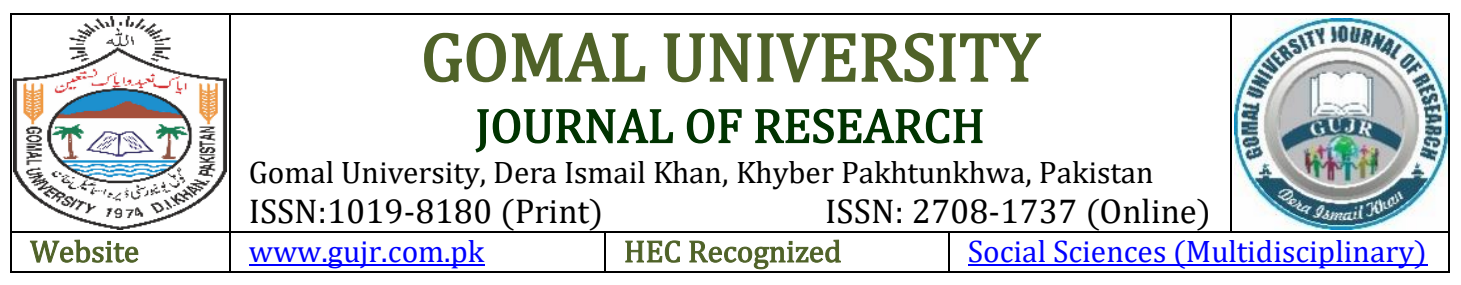

\title{
EXPLORING THE INFLUENCE OF LEADERSHIP STYLES ON PROFESSIONAL MOTIVATION
}

\author{
Afshan Jabeen ${ }^{1}$, Muhamamd Asghar Khan ${ }^{2}$ \& Mehwish Manzoor ${ }^{3}$
}

${ }^{1}$ Senior Subject Specialist Physical Education, School Education Department, Punjab, Pakistan 2Instructor Physical Education, Elementary \& Secondary Education Department, KP, Pakistan ${ }^{3}$ Lecturer, Department of Sports Sciences \& Physical Education, University of Narowal, Pakistan

\section{\begin{tabular}{l|l} 
ARTICLE INFO & ABSTRACT
\end{tabular}}

Keywords:

Influence, Leadership

Styles, Professional

Motivation

The present study was an attempt to examine influence of leadership styles upon professional motivation of lecturers (PE). The population of this current research comprised of the Lecturers (PE) performing in all government public colleges in Punjab. No sampling technique was preferred due to the accessible population in a particular study. Two self-designed, Likert type scales (the leadership style and professional motivation) were used for collecting of the required data. Overall, 80\%

Article History:

Date of Submission:

04-01-2020

Date of Acceptance:

21-12-2020

Date of Publication:

31-12-2020 return response rate was recorded. The collected data were tabulated and analyzed using both the descriptive and inferential statistics. The formulated hypotheses were tested with a significant level of 0.5. The study results from regression show significant influence of leadership styles on the professional motivation of lecturers. Similarly, prediction of professional motivation through the leadership styles over stepwise regression also provides the information about the dominant role of the transformational leadership style as compared to other leadership styles.

\section{(c) (1) (8)}

Afshan Jabeen: ajmalik54@gmail.com

Corresponding Author

DOI $\quad$ https://doi.org/10.51380/gujr-36-02-08

2020 Gomal University Journal of Research

\section{INTRODUCTION}

For each research study, an introduction is the ground-work which clarifies the background to need of particular research work. The introduction provides a Birds-eye view of the entire story. In this regard, this study has been conducted in the context of public sector colleges where for the last many years there have been leadership crises (Farazmand, 2017). There is an acute need of conducting real-world studies to explore the current leadership situation in the public sector colleges of Punjab, Pakistan (Awan \& Mahmood, 2010). The current study is in line with same idea to record the opinion of faculty members in the college sector about the ongoing leadership, its problems, strengths, weaknesses and possible improvements which can be introduced into 
the current environment for getting better results on the part of leaders in the college sector. In this connection, the leadership is most influential phenomenon with respect to various outcome concerning employees and concerned organization (Irfan \& Nawaz, 2016). Similarly, the leader is a person who molds the different features of the personality of the staff members or followers through individualized consideration (Irfan, Qureshi, Saqib \& Aman, 2019) and inspirational motivation to control the modification in the attitudes, behavior, commitment, motivation and performance.

To create and maintain a sense of vision, culture, and interactions with each other are the second name of leadership (Erkutlu \& Chafra, 2006). Successful leaders are more energetic and fuller of life and have the ability and expertise to obtain the challenging goals and the highest level of success. They have always a desire or aim to move ahead. They have the physical, mental and psychological strength to lead their team (Daft, 2014). Effective leaders are consistent and full of determination. They take initiatives and corrective actions without any guidance from others in accomplishing a task (Northouse, 2018). A motivated leader is a role model for their staff and also influences or stimulates them towards success. Leadership is not an effortless thing. It is defined in many different ways. Bass and Bass (2008) explained that leadership is the ability to encourage, motivate and direct the staff by using the power and position. According to Okumbe (2013), the leadership is the basic source of helping and motivating the staff members to work passionately for obtaining the set objectives. On the other side, Oladele (2005) concluded that the motivation responses to the queries that why the people perform certain behaviors or tasks. Therefore, this is called "human motives". Primarily, a person feels some desires or forces that motivate the psychological process and circumstantial aspects wherein they show some type of behavior.

Webb (2007) also found that leaders or heads of the institution must focus on personal feelings and intellectual stimulation concerning employee's motivation. Judge and Piccolo (2004) also confirmed that there is a positive effect of the transformational leadership style upon employees' motivation. The previous literature supports this statement with significant evidence. Barbuto and wheeler (2006) described how intrinsic motivation is based upon fun, emotions, self-worth and trust, the same traits that are required in the transformational style of leadership. Head of institutions understand their power and authority and also know about their authority source: their status, their capability, and their appeal to inspire others. They have an impact of their leadership styles on the teachers' motivation through set dynamics, discipline, communication, training and reward (Western, 2019). There are many styles of leadership, as transformational, autocratic, charismatic, transactional and visionary leadership (Irfan \& Nawaz, 2016). However, the present research study aimed to determine and examine the influence of the transactional, transformational, and the laissez-faire leadership styles upon the professional motivation of the lecturers (PE), their attitudes and performance and subsequently, their institutional oriented ventures.

\section{LITERATURE REVIEW}

Leadership significantly contributes to the success and failure of an institution. The institutional leadership makes or breaks the positivity, motivation of the teachers as well as the students (Day, Elliot \& Kington, 2005). After studying the leadership phenomena for decades, literature has identified different leadership styles. Leadership is known as the human factor that connects a team and motivates them towards obtaining set goals and renovates the potential into reality 
(Ng'ethe, Namusonge \& Iravo, 2012). According to Okumbe (2013) leadership is a basic source of helping and motivating the staff members to work passionately for obtaining set goals. The author further described that it is a human factor that could bond staff members together and inspires them to achieve targets by changing group abilities into a reality. In various spheres of life, there is continuously discussed topic that whether managers are born or build up. Reflecting upon the motivation debates, it's cleared that human beings have different personalities along with a large number of characteristics. Knafo, Zahn, Hulle, Robinson and Rhee (2008) indicated that motivation brings hereditary through influences and environment. So, the current research study tried to find out as well as to build up the effect/role of heads' leadership styles on teachers' motivation.

Additionally, Schunk, Pintrich \& Meece (2008) argued that motivation is process, which means that it has been implemented as from our actions as expressions. The teacher's motivation and effectiveness are the corresponding features with the effectiveness and quality of leader (Fullan, 2007). Insurance and comprehension of the motivation of the workers should be discovered by the organizations and the managers because this is the main aspect in determining the success and failure of an institution (Samuel \& Chipunza, 2009). Literature and organizational studies indicate that the motivational work theories are classified into two types (Proctor, Moore, Gao, Bradlee, Hood \& Ellison, 2003). Motivation can enhance the performance of the teacher/worker so the set objectives can be obtained in a better way. The performance and behavior of a worker can be changed through motivation. According to the situation/demand, a person has different motivation levels (Robbins, Judge, \& Sanghi, 2005). So, it's concluded that motivation is too essential for the performance of teachers and institutions. Even then in an institution, a skillful teacher cannot show her/his optimal level of the performance without motivation. Moreover, physical education teachers have a vital role in environment of learning and teaching. If teachers are not well stimulated and committed then the required institutional objectives can never be obtained.

These days, educators have a general complaint against the student's difficulty in the learning process during class and also found that the pupils are not well motivated about learning. So, it can be said that it is very difficult to stimulate the pupils if teaching staff are not motivated. Jesus and Lens (2005) explained that the well-motivated teachers make an effort for reforms implementation which is originated through policymakers. The motivation of the teacher has the main role in the excellence of education. The desired objectives and goals cannot be obtained without motivated and effective teachers. The above-mentioned studies were carried out in the various corners of the world with several scopes, different genders, and sample sizes, different independent, and dependent variables, moderate, extraneous and demographic variables. The previous studies, historical information, library books, catalogs, the Internet and databases have a key role to play in connection with reaching the gaps in literature. The concentrated literature review reveals that there is no studies shortage that focused on leadership style and employees' motivation. But it is very rare to find research studies that had been conducted for investigating the effect of leadership styles upon professional motivation in public sector colleges generally and especially in province of Punjab, Pakistan. Due to some uncertain situations like, poverty, unemployment, and migrations, Pakistani environment changed dramatically, which has badly affected each individual in the country. The conceptual framework provides research gap for the study. 
Figure 1

Theoretical Framework

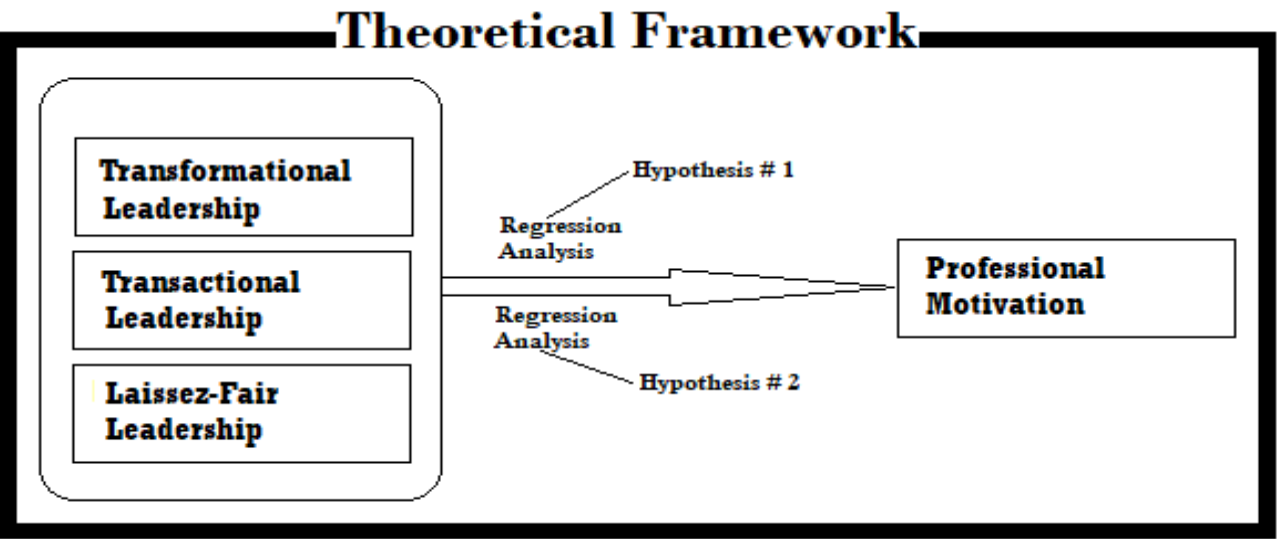

\section{Objectives \& Hypotheses}

Each and every research study is always based upon certain objectives which are aimed to be achieved. In this connection, the following are objectives of the current research study aligned with research hypotheses that are aimed to achieve by using different statistical procedures and tools.

1. To examine the influence of leadership styles of head of institution on the professional motivation of the lecturers in the Physical Education, at the college level (hypothesis \# 1).

2. To examine prediction of professional motivation over the leaderships' styles by using the multiple regression to examine the predictive role of leadership styles (hypothesis \# 2).

\section{RESEARCH METHODOLOGY}

This study aimed at determining the influence of different leadership styles (Transformational, Transactional \& Laissez-faire) upon professional motivation of lecturers in Physical Education working in Higher Education Department Punjab, Pakistan. Two hypotheses were formulated to explore the objectives of the study. Descriptive research design with the survey approach and quantitative method was adopted that were already used by different researchers. The study population consisted of 366 male and 210 female lecturers in Physical education. As list of these 576 individuals was available and they were supposed to be easily contacted, the census method was used and all the individuals in the population were surveyed for data collection. According to official record (Higher education department, Punjab [HED, 2019]) the existing number of government degree colleges for women and boys and working lecturers in physical education as under:

Table 1

Detailed description of Population before and after Data Collection

\begin{tabular}{cccc}
\hline Total Ccolleges & Lecturers (Male) & Lecturers (Female) & Return Response Rate \\
\hline 576 & 210 & 366 & 439 \\
\hline
\end{tabular}

Web Source: www.hed.punjab.gov.pk (2019) 
As, the as present study dealt with two different variables i.e., leadership styles and professional motivation, therefore two As, the present study dealt with two different variables i.e., leadership styles and the professional motivation, therefore two different research instruments were used. Leadership Style Scale was developed to explore the leadership style of the heads as perceived by lecturers while Professional Motivation Scale (PMS) was designed to measure the motivation level of lecturers. All two research instruments were developed on a 5-point scale. The research instruments were piloted on 30 lecturers (these lecturers were not included in the final data collection) and validated in light of the recommendations of o6 experts of the field accordingly. For this purpose, the content validity approach was applied in the present study. The Cronbach's alpha reliability coefficients values for the research instruments were as the leadership style (Transformational .804, Transactional .818 \& Laissez-faire .800 \& Total leadership styles .844); and motivation .839 . The researcher herself visited around 80 colleges while the remaining respondents were sent the questionnaires through postal services. The response rate (439 out of 546) was $80 \%$. Descriptive and inferential statistics were used to draw conclusions. SPSS 20 was used for data analyses. Frequencies, percentages, mean, and Standard deviation were used to describe the collected data. While the inferential statistic was used to test the formulated hypothesis.

\section{RESULTS OF STUDY}

The results obtained through statistical procedures have been presented in this section wherein different tools for the analysis have been applied to get the descriptive as well as the inferential results.

\section{Table 2}

Showing Demographics- Wise Frequencies \& Percentages of Participants

\begin{tabular}{llcc}
\hline \multicolumn{1}{c}{ Demographics } & Category & Frequency & Percent \\
\hline Gender & Male & 292 & $66.5 \%$ \\
Locality & Female & 147 & $33.5 \%$ \\
& Urban & 254 & $57.9 \%$ \\
Marital status & Rural & 185 & $42.1 \%$ \\
& Married & 323 & $73.6 \%$ \\
Educational & Unmarried & 116 & $26.4 \%$ \\
Qualification & MA/MSC & 306 & $69.7 \%$ \\
& M.Phil & 128 & $29.2 \%$ \\
Professional & PhD & 05 & $01.1 \%$ \\
Qualification & JPPE & 44 & $10.0 \%$ \\
& B.ED & 198 & $45.1 \%$ \\
& M.ED & 73 & $16.6 \%$ \\
Teaching Experiences & Any other & 27 & $06.2 \%$ \\
& Not any one & 97 & $22.1 \%$ \\
& 1 to 5 years & 185 & $42.1 \%$ \\
Total Respondents & 6 to 10 years & 100 & $22.8 \%$ \\
\hline
\end{tabular}


Overall, 439 participants respond positively in the present research. In the above table, $66.51 \%$ (292) were male participants while 33.49\% (147) were female participants. This table shows that the total urban respondents in the present research were $57.66 \%$ (254) and remaining were rural participants which were $42.14 \%$ (185). The following table also shows the respondents' marital status. Total married participants in research were $73.58 \%$ (323) and unmarried participants were $26.42 \%$ (116). Likewise, in identical table, total MSc/MA participants were 69.70\% (306), M.Phil participants were 29.2\% (128) and Ph.D. participants were 1.14\% (5). Moreover, above table also demonstrates professional qualification of the respondents. Holders of JDPE degree were $10 \%$ (44), B.ED degree was 45.1\% (198), whereas 16.6\% (73) were M.ED degree holders and $6.2 \%$ (27) were any other while $22.1 \%$ (97) participants responded the option "not anyone". A similar table indicates the teaching experience's percentages of the participants of the present research. Total participants that have experience of teaching from 1-5 (years) were 42.1\% (185), 6-10 (years) were $22.8 \%$ (100), 11-15 (y) were $15.7 \%$ (69) and more than 15 (years) were $19.4 \%$ (85).

H1: The Leadership Styles have a Significant Influence on Professional Motivation

Table 3

Model Summary

\begin{tabular}{cccccc}
\hline Model & R & R Square & Adjusted R2 & SE Estimate & Durbin-Watson \\
\hline 1 & $.586 \mathrm{a}$ & .343 & .339 & .577 & 1.867 \\
\hline
\end{tabular}

Table 4

ANOVA Statistics

\begin{tabular}{|c|c|c|c|c|c|c|}
\hline \multicolumn{2}{|c|}{ Model } & Sum Squares & Df & Mean Square & $\mathrm{F}$ & Sig. \\
\hline 1 & Regression & 75.686 & 3 & 25.229 & 75.762 & $.000 \mathrm{~b}$ \\
\hline & Residual & 144.854 & 435 & .333 & & \\
\hline & Total & 220.540 & 438 & & & \\
\hline
\end{tabular}

a. Predictors: Transformational, Transactional \& Laissez-faire

b. Dependent Variable: Professional Motivation

Table 5

Coefficients of Regression

\begin{tabular}{llccccccc}
\hline Model & \multicolumn{2}{c}{$\begin{array}{c}\text { Unstandardized } \\
\text { Coefficients }\end{array}$} & $\begin{array}{c}\text { Standardized } \\
\text { Coefficients }\end{array}$ & $\mathrm{T}$ & Sig. & \multicolumn{2}{c}{$\begin{array}{c}\text { Collinearity } \\
\text { Statistics }\end{array}$} \\
\hline \multirow{3}{*}{1} & $\mathrm{~B}$ & $\mathrm{SE}$ & Beta & & & Tolerance & VIF \\
(Constant) & 1.067 & .221 & & 4.837 & .000 & & \\
& Transformational & .498 & .044 & .483 & 11.44 & .000 & .847 & 1.181 \\
& Transactional & .135 & .050 & .122 & 2.687 & .007 & .734 & 1.363 \\
& laissez-faire & .110 & .049 & .107 & 2.258 & .024 & .668 & 1.497 \\
\hline
\end{tabular}

The first hypothesis was about prediction of professional motivation over predicting variables (transformational, transactional and laissez-faire styles). The results show that the predictors (transformational, transactional and laissez-faire) are responsible to bring 34\% variation in the professional motivation. The results also revealed that predictors have significant impact on the professional motivation like (transformational leadership style: Beta $=.498 \& \mathrm{P}$-value $=.000$ ), 
Jabeen et al... Exploring The Influence Of

(transactional leadership style: Beta $=.135 \&$ P-value $=.007$ ) and (laissez-faire leadership style: Beta $=.110$ \& P-value $=.024)$. Therefore, from results, it is concluded that the transformational leadership style is effective in predicting professional motivation among lecturers in physical education in a particular context under study. Thus, from results, hypothesis $\mathrm{H} 1$ is accepted and substantiated.

H2: Prediction of Professional Motivation Through Stepwise Regression

Table 6

Model Summary (Reression-Stepwise-2)

\begin{tabular}{cllrrrrrrr}
\hline & & \multicolumn{1}{c}{ Change Statistics } \\
\hline Model & R & \multicolumn{1}{c}{$\mathrm{R}^{2}$} & Adj-R & SEE & R2-Ch & F Change & df1 & df2 & Sig. F-Ch \\
\hline 1 & $.556^{\mathrm{a}}$ & .309 & .307 & .59 & .309 & 195.10 & 1 & 437 & .000 \\
2 & $.579^{\mathrm{b}}$ & .335 & .332 & .580 & .027 & 17.602 & 1 & 436 & .000 \\
3 & $.586^{\mathrm{c}}$ & .343 & .339 & .577 & .008 & 5.098 & 1 & 435 & .024 \\
\hline
\end{tabular}

Table 7

ANOVA Statistics (Regression-Stepwise-2)

\begin{tabular}{llccccc}
\hline Model & Sum Squares & Df & Mean Square & F & Sig. \\
\hline 1 & Regression & 68.072 & 1 & 68.072 & 195.105 & $.000^{\mathrm{b}}$ \\
& Residual & 152.468 & 437 & .349 & & \\
& Total & 220.540 & 438 & & & \\
2 & Regression & 73.988 & 2 & 36.994 & 110.060 & $.000^{\mathrm{c}}$ \\
& Residual & 146.551 & 436 & .336 & & \\
& Total & 220.540 & 438 & & & \\
3 & Regression & 75.686 & 3 & 25.229 & 75.762 & $.000^{\mathrm{d}}$ \\
& Residual & 144.854 & 435 & .333 & & \\
& Total & 220.540 & 438 & & & \\
\hline
\end{tabular}

Table 8

Coefficients of (Regression- Stepwise-2)

\begin{tabular}{llccccc}
\hline \multirow{2}{*}{ Model } & \multicolumn{2}{c}{$\begin{array}{c}\text { Unstandardized } \\
\text { Coefficients }\end{array}$} & $\begin{array}{c}\text { Standardized } \\
\text { Coefficients }\end{array}$ & $\mathrm{t}$ & Sig. \\
\cline { 1 - 5 } & & $\mathrm{B}$ & Std. Error & Beta & & \\
\hline \multirow{2}{*}{2} & (Constant) & 1.807 & .159 & & 11.387 & .000 \\
& Transformational & .573 & .041 & .556 & 13.968 & .000 \\
& (Constant) & 1.181 & .216 & & 5.476 & .000 \\
& Transformational & .528 & .042 & .512 & 12.693 & .000 \\
& Transactional & .188 & .045 & .169 & 4.196 & .000 \\
3 & (Constant) & 1.067 & .221 & & 4.837 & .000 \\
& Transformational & .498 & .044 & .483 & 11.441 & .000 \\
& Transactional & .135 & .050 & .122 & 2.687 & .007 \\
& Laissez-faire & .110 & .049 & .107 & 2.258 & .024 \\
\hline
\end{tabular}

a. Predictors: Transformational, Transactional \& Laissez-faire

b. Dependent Variable: Professional Motivation 
The second hypothesis was related to the prediction of the professional motivation of lecturers through leadership styles (transformational, transactional \& laissez-faire) over stepwise regression to examine the dominance of a particular leadership style. The results provide the $\mathrm{R}$ square for all the three models (30\%, 33\% \& 34\%) respectively. Similarly, the coefficient of the regression shows that among the three models, the first model is more effective as in this model; the Beta value for transformational leadership is greater than other styles shown in the other two regression models. Therefore, results confirmed that transformational leadership style is a more dominant predictor in determining the professional motivation of the LPEs. Thus, H2 is accepted.

\section{DISCUSSION}

The study aimed to examine the influence of Leadership styles (transactional, transformational, and laissez-faire) upon the professional motivation of lecturers (PE) at the college level, Punjab, Pakistan. Present research shows the positive influence of transactional, transformational, and laissez-faire styles of leadership upon the professional motivation of lecturers (PE). With respect to determine the impact of leadership styles of HOIs upon professional motivation of college LPEs, the study results found that transformational leadership style has significant impact on the professional motivation with R square (34\%) as (transformational leadership style $=.49 \%$, transactional leadership style $=.13 \%$ and laissez-faire leadership style $=.11 \%$ ). Thus, the results show the effectiveness of the transformational leadership style in determining the professional motivation. Similarly, Ahmad, Abbas, Latif and Rasheed (2014) confirmed significant impact of transformational leadership style upon the employees' motivation and Kalar and Wright (2007) also supported that the transformational style of leadership is generally based upon methods of intrinsic motivation towards employees. Previous literature supports statement with Barbuto and Wheeler (2006) describing that how the teachers' professional motivation depends upon emotions, self-worth and trust, the same traits that are required in the transformational style of leadership.

Chaudhry and Javed (2012) described that transformational leadership gives emphasized on the higher order of necessities than the rewards system and short-term goals. Above mentioned literature proved that there is the powerful impact of the transformational style of leadership towards employees' motivation supported by Irfan and Nawaz (2016) and Irfan, Qureshi, Saqib and Aman (2019). With regard to predicting the professional motivation of LPEs through the HOIs' leadership styles, the results show that transformational leadership is more effective in predicting professional motivation as compared to the other leadership styles. It means that the transformational leadership style is more effective towards the motivation of lecturers through its artistic attributes. The results of the current study are in line with the results of the previous studies from different dimensions as conducted by the researcher in similar or diverse contexts (Limsili \& Ogunlana, 2008; Lo, Ramayah \& Songan, 2010; Rehman, Shareef \& Mahmood, 2012; Amin, Shah \& Tatlah, 2013; Sharif, Nazarudin, \& Omar, 2015; Fedirko \& Campo, 2018). Thus, study provides enough evidence about prediction of professional motivation through leadership styles. Consequently, the study is expected to provide significant and valuable addition to the existing databases of knowledge about leadership styles and professional motivation in different contexts.

\section{CONCLUSION}

This study aimed at determining the influence of different leadership styles (transformational, transactional \& laissez-faire) upon the professional motivation of lecturers in physical education 
working in higher education department Punjab, Pakistan. There were three types of leadership styles of head of the institutions entertained as independent variables like the transformational, transactional and laissez-faire leadership styles. The dependent variables of the study were the professional motivation of college LPEs. On basis of data analysis, it was concluded that there is a significant positive impact of all leadership styles on professional motivation however, the role of transformational leadership style was more dominant as compared to the transactional and laissez-faire leadership style. The results of present study supported over existing research studies revealed due to the transformational leadership style, a positive variation was found in the motivation of LPEs. Therefore, it is concluded that the transformational leadership style of head of institutions is more powerful and dominant towards motivation of lecturer in physical education of the H.E.D, Punjab, Pakistan. On the basis of study results, it was suggested that the principals may set the clear and vivid teaching and sport objectives to be achieved as well as the administrator may create a respectful environment in institution to achieve academic and sports goals.

\section{REFERENCES}

Ahmad, F., Abbas, T., Latif, S., \& Rasheed, A. (2014). Impact of transformational leadership on employee motivation in telecommunication sector. Journal of management policies and practices, 2(2), 11-25.

Amin, M., Shah, S., \& Tatlah, I. A. (2013). Impact of HOIs/Directors' Leadership Styles on Job Satisfaction of the Faculty Members: Perceptions of the Faculty Members in a Public University of Punjab, Pakistan. Journal of Research \& Reflections in Education (JRRE), $7(2)$.

Awan, M. R., \& Mahmood, K. (2010). Relationship among leadership style, organizational culture and employee commitment in university libraries. Library management.

BarbutoJr, J. E., \& Wheeler, D. W. (2006). Scale development and construct clarification of servant leadership. Group \& Organization Management, 31(3), 300-326.

Bass, B. M., \& Bass, R. (2008). Handbook of leadership: Theory, research, and application. Free Press.

Chaudhry, A. Q., \& Javed, H. (2012). Impact of transactional and laissez faire leadership style on motivation. International Journal of Business and Social Science, 3(7).

Daft, R. L. (2014). The leadership experiences. Cengage Learning.

Day, C., Elliot, B., \& Kington, A. (2005). Reform, standards and teacher identity: Challenges of sustaining commitment. Teaching and teacher Education, 21(5), 563-577.

Erkutlu, H. V., \& Chafra, J. (2006). Relationship between leadership power bases and job stress of subordinates: example from boutique hotels. Management Research News.

Farazmand, A. (2017). Governance reforms: The good, the bad, and the ugly; and the sound: Examining the past and exploring the future of public organizations. Public Organization Review, 17(4), 595-617.

Fedirko, R., \& Sanz Campo, S. (2018). Leadership in IT, employees' motivation and retention.

Fullan, M. (2007). Leading in a culture of change. John Wiley \& Sons.

Irfan, U. K.., \& Nawaz, A. (2016). A comparative analysis of Leadership Theories: A Review. Gomal University Journal of Research, IV, 20-31.

Irfan, U. K.., \& Nawaz, A. (2016). The leadership styles and the employees' performance: A review. Gomal University Journal of Research, 32 (2), 144-150. 
Irfan, U. K.., Qureshi, Q., Saqib, M., \& Aman, U. (2019). The Support of Individualized Consideration in relationship between Interactional Justice and Employee Performance. City University Research journal. 10 (3), 361-376.

Jesus, S. N., Lens, W. (2005). An integrated model for the study of teacher motivation. Applied Psychology: An International Review, 54(1), 119-134.

Judge and R. Piccolo (2004). Transformational and Transactional Leadership: A Meta-Analytic Test of Their Relative Validity. Journal of Applied Psychology, 89, Pg.755.

Kalar, T., \& Wright, D. (2007). Leadership theory and motivation of medical imaging employees. Radiology management, 29(6), 20.

Knafo, A., Zahn, C., Hulle, C., Robinson, J. L., \& Rhee, S. H. (2008). The developmental origins of a disposition toward empathy: Genetic and environmental contributions. Emotion, 8(6), 737.

Limsili, K., \& Ogunlana, S. O. (2008). Performance and leadership outcome correlates of leadership styles and subordinate commitment. Engineering, Construction and Architectural Management, 15(2), 164-184

Lo, M. C., Ramayah, T., Min, H. W., \& Songan, P. (2010). The relationship between leadership styles and organizational commitment in Malaysia: Role of leader-member exchange. Asia Pacific business review, 16(1-2), 79-103.

Ng'ethe, J. M., Namusonge, G. S., \& Iravo, M. A. (2012). Influence of leadership style on academic staff retention in public universities in Kenya. International journal of business and social science, $3(21)$.

Northouse, P. G. (2018). Leadership: Theory and practice. Sage publications.

Okumbe, J. A. (2013). Educational Management Theory and Practice. Nairobi: Nairobi University Press.

Oladele, J. O. (2005). Fundamental of educational psychology. Handbook for Education students and teachers (5th Ed.). Lagos: Johns. Lad Publishers Ltd.

Proctor, M., Moore, L., Gao, D., Bradlee, L., Hood, Y., \& Ellison, C. (2003). Television viewing and change in body fat from preschool to early adolescence: The Framingham Children's Study. International journal of obesity, 27(7), 827.

Rehman, U., A. Shareef, A Mahmood (2012) Perceived Leadership Styles and Working motivation.

Robbins, S., Judge, T., \& Sanghi, S. (2005). Organizational behavior (8th ed.). New Delhi: Pearson Education. Christian Higher Education, 8(6), 53-71

Samuel, M. O., \& Chipunza, C. (2009). Employee retention and turnover: Using motivational variables as a panacea. African Journal of Business Management, 3(8), 410-415.

Schunk, D., Pintrich, P., \& Meece, J. (2008). Motivation in Education, Theory, Research and Applications, USA: Pearson Education Inc.

Sharif, S., Nazarudin, M. N., \& Omar, M. S. (2015) Headmaster's Transformational Leadership and Teacher's Organizational Commitment in Primary School.

Web Source. (2019). www.hed.punjab.gov.pk (2019).

Webb, K. (2007). Motivating peak performance: Leadership behaviors that stimulate employee motivation and performance. Christian Higher Education, 6(1), 53-71.

Western, S. (2019). Leadership: A critical text. SAGE Publications Limited. 